\title{
Limiting Current of Oxygen Reduction on Gas-Diffusion Electrodes for Phosphoric Acid Fuel Cells
}

\author{
Li, Qingfeng; Gang, Xiao; Hjuler, Hans Aage; Berg, Rolf W.; Bjerrum, Niels
}

Published in:

Journal of The Electrochemical Society

Link to article, DOI:

$10.1149 / 1.2059286$

Publication date:

1994

Document Version

Publisher's PDF, also known as Version of record

Link back to DTU Orbit

Citation (APA):

Li, Q., Gang, X., Hjuler, H. A., Berg, R. W., \& Bjerrum, N. (1994). Limiting Current of Oxygen Reduction on GasDiffusion Electrodes for Phosphoric Acid Fuel Cells. Journal of The Electrochemical Society, 141(11), 31143119. https://doi.org/10.1149/1.2059286

\section{General rights}

Copyright and moral rights for the publications made accessible in the public portal are retained by the authors and/or other copyright owners and it is a condition of accessing publications that users recognise and abide by the legal requirements associated with these rights.

- Users may download and print one copy of any publication from the public portal for the purpose of private study or research.

- You may not further distribute the material or use it for any profit-making activity or commercial gain

- You may freely distribute the URL identifying the publication in the public portal 
total volume fraction of particles

in a dispersion

olume traction of type-i particles in a dispersion

\section{REFERENCES}

1. R. Alkire, This Journal, 120, 900 (1973).

2. D. C. Eardley, D. Handley, and S. P. S. Andrew, Electrochim. Acta, 18, 839 (1973).

3. K. Kusakabe, S. Morooka, and Y. Kato, J. Chem. Eng. Jpn., 19, 43 (1986).

4. R. E. Plimley and A. R. Wright, Chem. Eng. Sci., 39, 395 (1984)
5. J. K. Lee, L. W. Shemilt, and H. S. Chun, J. Appl. Electrochem., 19, 877 (1989).

6. S. C. Yen and C. Y. Yao, This Journal, 138, 2697 (1991).

7. P. M. Morse and H. Feshbach, Methods of Theoretical Physics, Part II, McGraw-Hill, New York (1953).

8. H. J. Keh and F. R. Yang, J. Colloid Interface Sci., 145, 362 (1991).

9. R. E. Meredith and C. W. Tobias, Advances in Electrochemistry and Electrochemical Engineering, Vol. 2, Chap. 2, John Wiley and Sons, Inc., New York (1962).

10. D. J. Jeffrey, Proc. R. Soc. London Ser. A, 335, 355 (1973).

\title{
Limiting Current of Oxygen Reduction on Gas-Diffusion Electrodes for Phosphoric Acid Fuel Cells
}

\author{
Li Qingfeng, Xiao Gang, H. A. Hjuler," R. W. Berg, and N. J. Bjerrum* \\ Material Science Group, Chemistry Department A, Technical University of Denmark, 2800 Lyngby, Denmark
}

\section{ABSTRACT}

Various models have been devoted to the operation mechanism of porous diffusion electrodes. They are, however, suffering from the lack of accuracy concerning the acid-film thickness on which they are based. In the present paper the limiting current density has been measured for oxygen reduction on polytetrafluorine-ethyl bonded gas-diffusion electrodes in phosphoric acid with and without fluorinated additives. This provides an alternative to estimate the film thickness by combining it with the acid-adsorption measurements and the porosity analysis of the catalyst layer. It was noticed that the limiting current density can be accomplished either by gas-phase diffusion or liquid-phase diffusion, and it is the latter that can be used in the film-thickness estimation. It is also important to mention that at such a limiting condition, both the thin-film model and the filmed agglomerate model reach the same expression for the limiting current density. The acid-film thickness estimated this way was found to be of $0.1 \mu \mathrm{m}$ order of magnitude for the two types of electrodes used in phosphoric acid with and without fluorinated additives at $150^{\circ} \mathrm{C}$.

The cathode of phosphoric acid fuel cells (PAFC) consists of a porous carbon substrate and a catalyst layer which is composed of a carbon-supported platinum catalyst bonded with polytetrafluoroethylene (PTFE). The presence of PTFE in the catalyst layer gives hydrophobicity so that the catalyst layer, during operation, is only partially in contact with acid. The performance of the electrode is dependent on a number of factors such as pore-size distribution, electrolyte composition, active surface area, and electrochemical kinetics.

The working mechanism of such an electrode as well as those used in molten carbonate fuel cells (MCFC) has been modeled by means of the thin-film model ${ }^{1,2}$ and more appropriately with the agglomerate and filmed agglomerate models. ${ }^{3-7}$ All of these approaches suffer from the drawback that the film thickness is not taken into account in the model in a satisfying way.

By fitting the theoretical expression for the initial slope of the polarization curves to the experimentally determined values on the basis of a simple thin-film model, Wilemski ${ }^{2}$ found an unlikely value, ca. $0.5 \mu \mathrm{m}$, for the electrolyte film thickness for a molten-carbonate fuel-cell ( $M C F C)$ cathode. On the other hand, by use of a theory of the liquid-film stability, the value of the molten carbonate film thickness on a $\mathrm{NiO}$ substrate was estimated to be $c a$. $0.003 \mu \mathrm{m}$, i.e., two orders of magnitude smaller.

Springer and Raistrick, ${ }^{9}$ in their ac impedance analysis, suggested that only by assuming the presence of an external electrolyte film covering the agglomerate was it possible to explain a separate low-frequency mass-transfer impedance loop, while the agglomerate itself could not lead to such a loop, therefore Yuh and Selman ${ }^{6}$ used the size of the low-frequency impedance loop for estimating the electrolyte film thickness. The thickness was estimated to be ca. $0.1 \mu \mathrm{m}$ by assuming that the low-frequency loop was

* Electrochemical Society Active Member. caused by a Nernst-type diffusion limitation in the electrolyte film.

On the other hand, Yuh and Selman ${ }^{5}$ used the limiting current supposedly measured at low oxygen concentration (less than $3 \%$ oxygen) ${ }^{10}$ to estimate the film thickness. By assuming that the limiting current was due to the oxygen diffusion through the film and was independent of gas composition, they found the film thickness to be $c a .0 .1 \mu \mathrm{m}$. As they pointed out later, ${ }^{6}$ the limiting current cannot always be observed on a MCFC cathode even at low partial pressure of oxygen; hence the observed limiting currents were suspected to be due to the depletion of the gaseous oxygen at high current levels.

In the present work, well-defined limiting currents have been measured on a PAFC cathode, and effort has been made to estimate the acid-film thickness by combining the limiting current, the electrode microstructure, and acid adsorption measurements for two kinds of electrodes and for $100 \%$ phosphoric acid electrolyte with and without fluorinated compounds. The success of fluorinated compounds as possible electrolyte additives for PAFC has been demonstrated in our previous papers, ${ }^{11,12}$ where promising compounds are specified such as potassium perfluorohexanesulfonate, $\mathrm{C}_{6} \mathrm{~F}_{13} \mathrm{SO}_{3} \mathrm{~K}$ (hereafter referred to as $\mathrm{C}_{6}$ salt), potassium nonafluorobutanesulfonate $\left(\mathrm{C}_{4} \mathrm{~F}_{9} \mathrm{SO}_{3} \mathrm{~K}\right)$, and perfluorotributylamine $\left[\left(\mathrm{C}_{4} \mathrm{~F}_{9}\right)_{3} \mathrm{~N}\right]$.

\section{Limiting Current Density for Gas-Diffusion Electrode Models}

A gas-diffusion electrode contains pores with a variety of pore sizes. From the conventional porosimetry, a set of data for cumulative pore volume $(V)$ and specific pore-wall surface $(A)$ as a function of pore radius $(r)$ can be obtained. It is known that the total pore volume $\left(V_{t}\right)$ and total specific surface area $\left(A_{t}\right)$ can be obtained by integration over a range of pores of increasing radius, assuming that the pores are cylindrical 


$$
\begin{gathered}
V_{\mathrm{t}}=\int_{0}^{\infty} d V(r) \\
A_{\mathrm{t}}=\int_{0}^{\infty} \frac{2 d V(r)}{r}
\end{gathered}
$$

The thin-film model.-This model assumes that, during normal operation of an electrode in contact with both the gas and the electrolyte on either side, there exists a critical pore radius $r_{\mathrm{c}}$. Pores with radii larger than $r_{\mathrm{c}}$ will be gas filled and supposedly acid filmed along pore walls, and those with radii smaller than $r_{\mathrm{c}}$ will be acid flooded. It is assumed that the flooding of the smaller pores is driven by capillary forces. The critical radius $r_{\mathrm{c}}$ is thus dependent on the balance

$$
r_{\mathrm{c}}=\frac{2 \sigma}{\Delta P} \cos \theta
$$

where $\sigma$ is the surface tension of the electrolyte, $\Delta P$ is the pressure difference between the gas and the liquid, and $\theta$ is the contact angle of the electrolyte.

In this context, parameters such as the acid-flooded pore volume $\left(V_{f}\right)$, the gas-filled pore volume $\left(V_{g}\right)$, and the acidfilmed specific surface area $\left(A_{\mathrm{g}}\right)$ can be defined by the equations

$$
\begin{aligned}
V_{\mathrm{f}} & =\int_{0}^{r_{\mathrm{c}}} d V(r) \\
V_{\mathrm{g}} & =\int_{r_{\mathrm{c}}}^{\infty} d V(r) \\
A_{\mathrm{g}} & =\int_{r_{\mathrm{c}}}^{\infty} \frac{2 d V(r)}{r}
\end{aligned}
$$

Since the thin-film models assume that all electrochemical processes take place in the film-covered pore walls of larger gas-filled pores, see Fig. 1, $A_{\mathrm{g}}$ as expressed by Eq. 6 might be assumed to be the electrochemically active area, whereas the acid-flooded pores are treated as electrochem ically inert. This assumption might not be true at lower current densities; however, in the vicinity of the limiting current density it is valid.

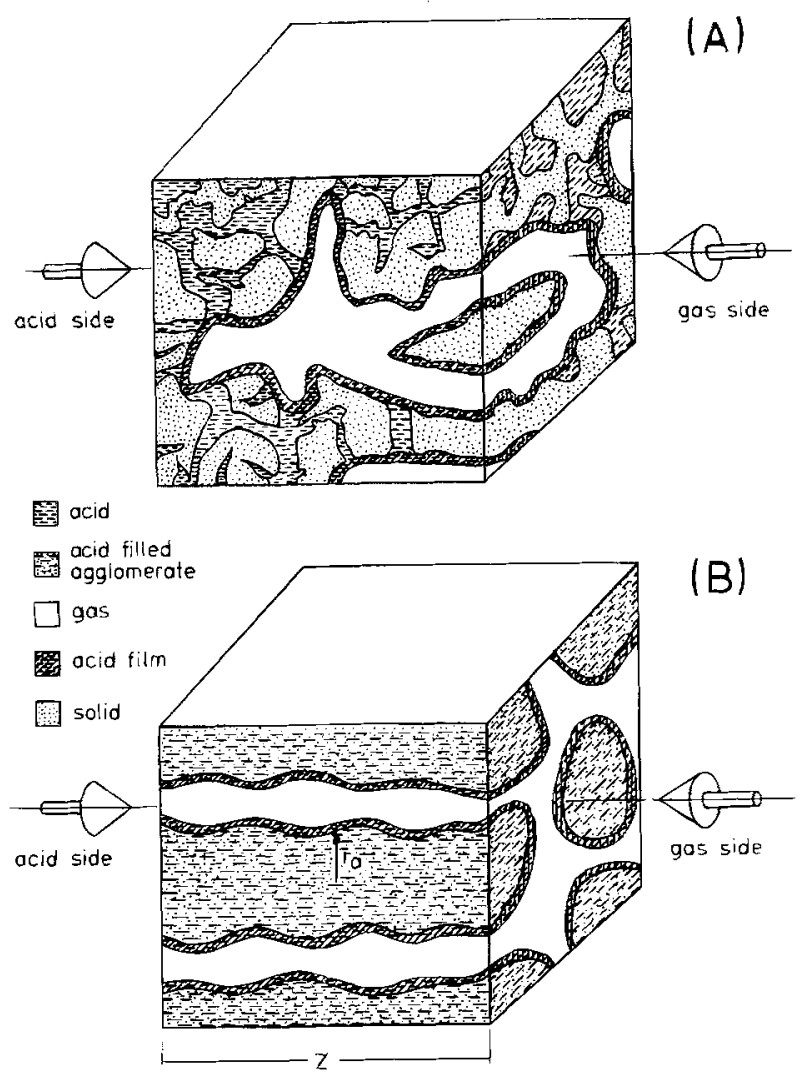

Fig. 1. (A) Thin-film model, and (B) filmed agglomerate model.
When the entire electrode process is rate determined by diffusion through the acid film of a dissolved reactant, e.g., oxygen in the case of $\mathrm{O}_{2}$ reduction, the true limiting current density $\left[i_{\mathrm{L}(\text { true })}\right]$, which is based on the actual reactive surface area along the pore walls, should be expressed by

$$
i_{\mathrm{L}_{\text {(true })}}=\frac{n F D c_{0}}{\delta}
$$

where $n$ is the number of electrons involved, $F$ is Faraday's constant, $D$ is the oxygen diffusion coefficient, $c_{o}$ is the solubility of oxygen, and $\delta$ is the film thickness. To relate the true limiting current density to the apparent limiting current density $\left(i_{L}\right)$ (which is based on the apparent sectional area and is experimentally measurable), one has

$$
i_{\mathrm{L}}=i_{\mathrm{L} \text { (true) }} \cdot A_{\mathrm{g}} \cdot z
$$

where $A_{\mathrm{g}}$ is the acid-filmed specific pore-wall surface area per unit volume of electrode $\left(\mathrm{cm}^{2} / \mathrm{cm}^{3}\right)$ and $z$ is the electrode thickness.

The filmed agglomerate model.-This model assumes that catalyst particles form elongated porous agglomerates (with micropores, see Fig. 1B). These agglomerates under working conditions are flooded and on the outside surface filmed by the electrolyte. The PTFE binders are assumed to create hydrophobic gas channels (macropores). When current is drawn from the electrode, reactant gas molecules diffuse through the macropores and dissolve into the electrolyte film. After diffusing through the film, the molecules react at active sites on the catalyst particles.

The porosity $\Theta$ of the agglomerate is defined as

$$
\Theta=V_{\mathrm{f}} /\left(V_{\mathrm{f}}+V_{\mathrm{s}}\right)
$$

where $V_{\mathrm{f}}$ is the agglomerate pore volume totally filled with acid and $V_{\mathrm{s}}$ is the solid volume. Assuming the agglomerate to be a wavy cylinder with a radius of $r_{\alpha}$, the number of agglomerates per unit volume electrode, $N$, can be expressed

$$
N=\left(V_{\mathrm{f}}+V_{\mathrm{s}}\right) /\left(\pi r_{\alpha}^{2} \tau_{\alpha} z\right)
$$

where $z$ is the electrode thickness and $\tau_{\alpha}$ is the agglomerate tortuosity correcting for the increased length.

If the surface area of $N$ agglomerates, excluding the ends, is denoted as $S_{\alpha}$, then

$$
S_{\alpha}=N 2 \pi r_{\alpha} z \tau_{\alpha}
$$

Combining Eq. 9, 10, and 11, one obtains

$$
r_{\alpha}=2 V_{f} / S_{\alpha} \Theta
$$

According to Kunz et al., " the surface area of all the agglomerates per unit volume of electrode, $S_{\mathrm{\alpha}}$, can supposedly be expressed by Eq. 6, i.e., equal to the gas-liquid interfacial area, $A_{\text {. }}$. Therefore, the limiting current due to the liquid-phase diffusion of the dissolved reactant through the acid film can be expressed by Eq. 8, valid for both the thin-film model and the filmed agglomerate model.

By means of acid-adsorption measurements for different electrodes, the acid-filled volume $V_{f}$ and the surface area of acid-filmed pore walls $A_{\mathrm{g}}$ or $S_{\alpha}$ can be determined from cumulative curves of the pore volume and surface area, and the acid film thickness can thus be calculated from the limiting currents by using Eq. 7 and 8.

\section{Experimental}

Chemicals.-The preparation of 100 weight percent (w/ o) $\mathrm{H}_{3} \mathrm{PO}_{4}$ from an aqueous 85 w/o Riedel-de Haën acid of analytical grade has been described previously. ${ }^{12}$ An electrolyte additive used in some of the experiments was potassium perfluorohexanesulfonate, $\mathrm{C}_{6} \mathrm{~F}_{13} \mathrm{SO}_{3} \mathrm{~K}$ (hereafter referred to as the $C_{6}$ salt) and was used as received from Riedel-de Haën.

Purified hydrogen ( $\geq 99.998$ volume percent (v/o), Hede Nielsen A/S) and oxygen ( $\geq 99.998 \mathrm{v} / \mathrm{o}, \mathrm{AGA}$ A/S) were used for the reference and working electrodes, respectively. 


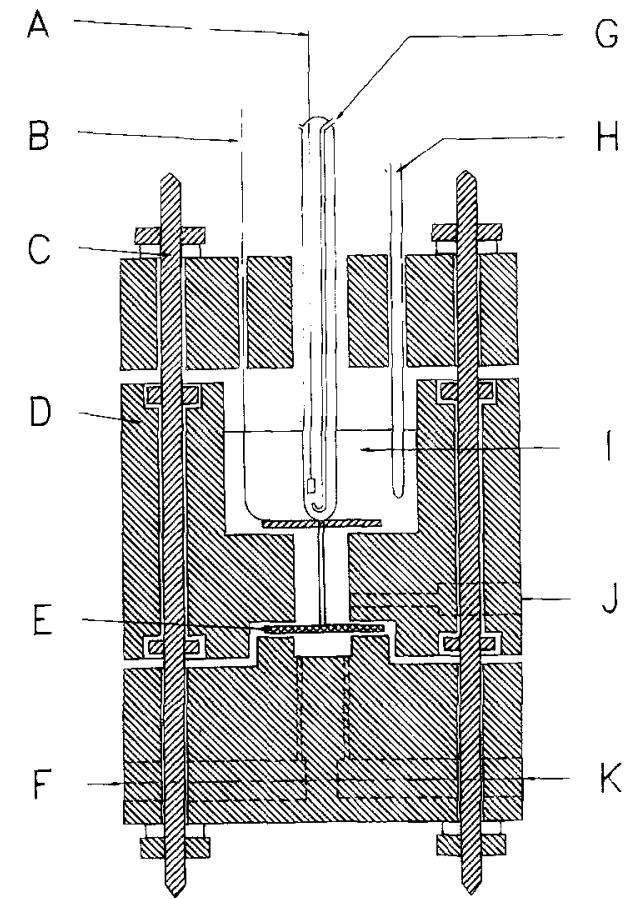

Fig. 2. PTFE half-cell assembly: $A$, reference electrode; $B$, counterelectrode; C, stainless steel screw; D, PTFE cell housing; E, working electrode; $F$, oxygen inlet; $G$, hydrogen inlet; $H$, thermocouple; $I$, electrolyte; J, nitrogen inlet; and $K$, oxygen (and water) outlet.

Electrodes.-Two kinds of gas-diffusion electrodes, type $A$ and $B$, were used for mercury-intrusion porosimetry, acid-adsorption, and half-cell polarization measurements. Electrode A was purchased from Giner, Inc., with $10 \mathrm{w} / \mathrm{o}$ $\mathrm{Pt} /$ carbon catalyst and a total platinum loading of $0.5 \mathrm{mg} /$ $\mathrm{cm}^{2}$. Electrode $\mathrm{B}$ was made in this laboratory by using $10 \mathrm{w} / \mathrm{o} \mathrm{Pt} /$ carbon catalyst and with a platinum loading of $0.5 \mathrm{mg} / \mathrm{cm}^{2}$.

PTFE half cell.-The PTFE half-cell assembly is sche matically presented in Fig. 2. The gas chamber was $12 \mathrm{~mm}$ id and $5 \mathrm{~mm}$ in height with gas inlet and outlet holes of 2 $\mathrm{mm}$ in diameter. The working gas-diffusion electrode is made of a circular disk (diam $22 \mathrm{~mm}$ ) with an area of 1.1 $\mathrm{cm}^{2}$ exposed to the gas and an area $0.28 \mathrm{~cm}^{2}(6 \mathrm{~mm}$ diam) exposed to the electrolyte. The counterelectrode was made of a platinum plate (diam $36 \mathrm{~mm}$ ) with a hole (diam $14 \mathrm{~mm}$ ) at the center. The distance between the counter- and working electrode was about $5 \mathrm{~mm}$. A reversible hydrogen electrode (RHE) was used as a reference electrode. The reference capillary was situated in the hole at the center of the counterelectrode pointing toward the working electrode. The distance between the capillary tip and the working electrode was adjustable.

During the experiments, the whole cell was placed in an oven, and the temperature was controlled at $150 \pm 1^{\circ} \mathrm{C}$.

Instruments and measurements.-Limiting currents were obtained by potential sweeps at the slow rate of $1 \mathrm{mV} / \mathrm{s}$. The potentiostat used was an electrochemical interface (SI 1286, Schlumberger Technologies, Ltd.). A current-interruption technique was used to correct the iR part of the potential by means of an oscilloscope (DSO 1602, Gould Electronic, Ltd.). The iR part of the potential was obtained by measuring the potential drop $25 \mu \mathrm{s}$ after the current was interrupted.

Gas flow was controlled by means of a valve and a flowmeter (Rotameter, Rota Apparate-und Maschinenbau, Dr. Hennig GmbH \& Co., KG).

Acid adsorption measurements were performed with the method proposed by Mori et al. ${ }^{13,14}$ The sample electrode disk was $1.4 \mathrm{~cm}$ in diam, and the measurements were performed at $150 \pm 1^{\circ} \mathrm{C}$.
Mercury intrusion porosimetry was performed for electrodes and carbon supports by the use of a porosimeter, Quautachrome Autoscan 60 . The pore volume and the porewall surface area of the catalyst layer were then derived.

\section{Results and Discussion}

Limiting current.-Figures 3 and 4 show two sets of typical polarization curves for the oxygen reduction in $100 \%$ phosphoric acid without (A) and with (B) the additive $\left(0.1 \mathrm{w} / 0 \mathrm{C}_{6}\right.$ salt) at $150^{\circ} \mathrm{C}$ for both electrode $\mathrm{A}$ (Fig. 3) and electrode B (Fig. 4). As the electrode potential increases, the responding curves display limiting currents, characterizing the diffusion determining step.

It can be seen that the limiting current increases with increasing oxygen flow rate. The reaction sequence of oxygen reduction on a gas-diffusion electrode is assumed to involve two diffusion steps, i.e., the diffusion of gaseous oxygen from the outer end of the porous electrode to the gas-electrolyte interface, and the diffusion of dissolved oxygen through the electrolyte film to the active sites.

At very low oxygen flow rates, the limiting current density appears to be caused by an oxygen-flow limitation according to Faraday's law. As the oxygen flow rate increases, the utilization of the gaseous oxygen decreases, i.e., the partial pressure of oxygen in the mixture of oxygen and water vapor will increase. If the electrode kinetics in the vicinity of the limiting current is rate determined by the gaseous diffusion of oxygen through the water vapor, this increase in the oxygen partial pressure in the gas phase at the electrode backing will result in an increased limiting current. This is demonstrated by Fig. 3 and 4.

As the oxygen flow rate increases further, the electrode process shifts into the range of diffusion control of the dissolved oxygen through the thin electrolyte film. This is indicated by the almost constant value reached by the limiting currents when the increase in oxygen flow rate does not
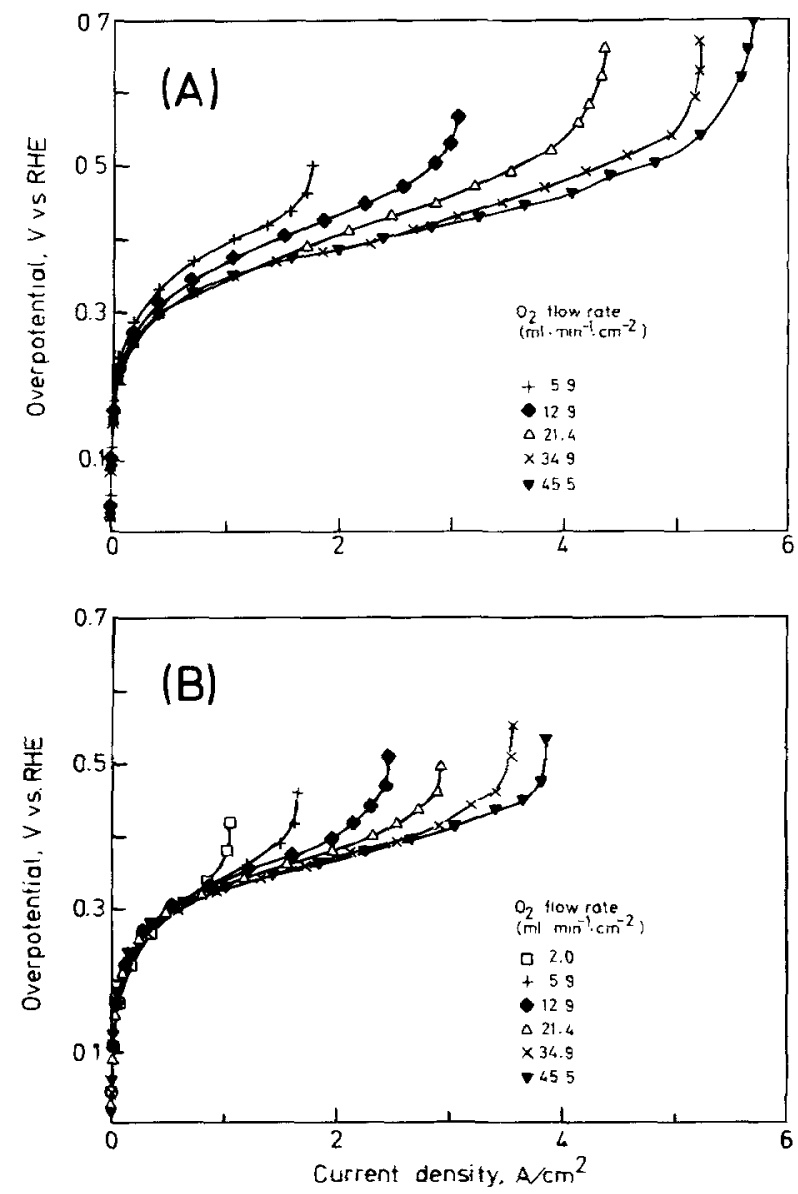

Fig. 3. Polarization curves for oxygen reduction on electrode $A$ in phosphoric acid without (A) and with $(B) C_{6}$ salt added at $150^{\circ} \mathrm{C}$. 

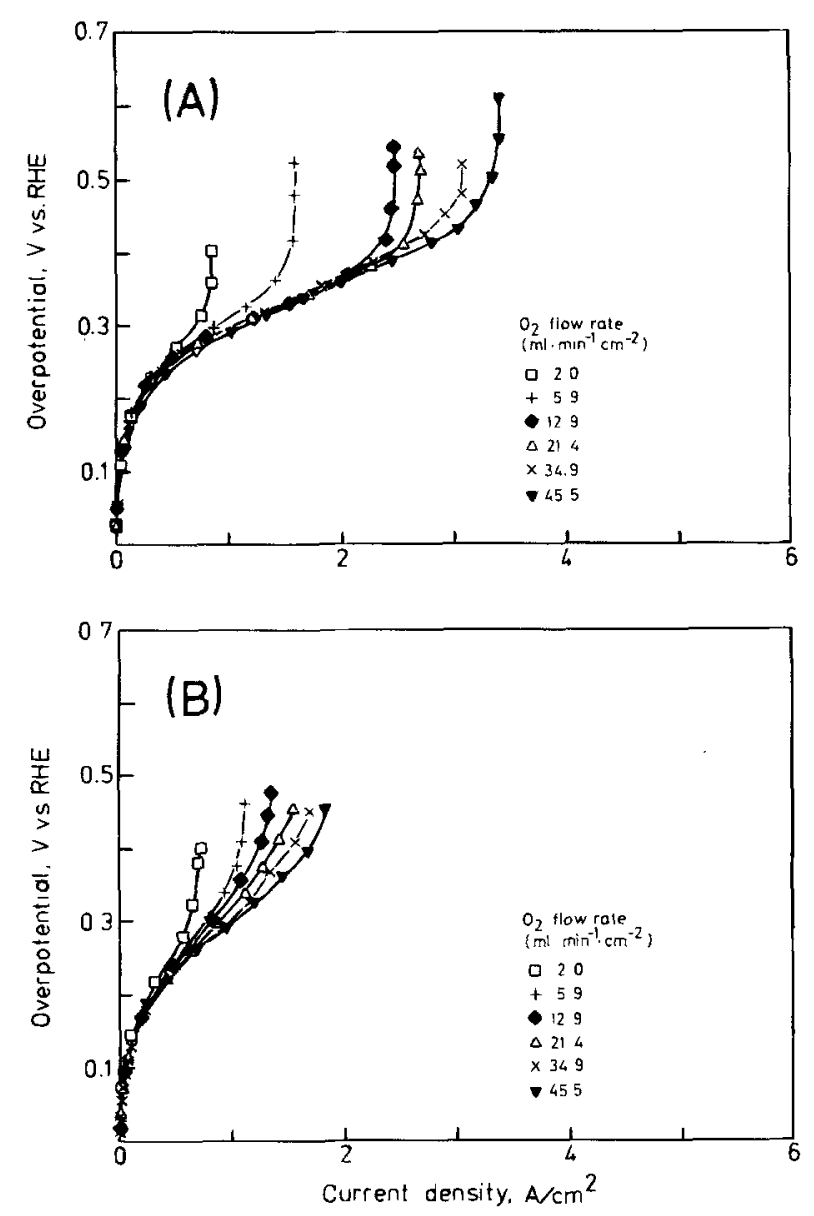

Fig. 4. Polarization curves for oxygen reduction on electrode $B$ in phosphoric acid without $(A)$ and with $(B) C_{6}$ salt added at $150^{\circ} \mathrm{C}$.

lead to any significant increase in the limiting current density (Fig. 5). This is further demonstrated when the total oxygen utilization is taken into the consideration. For instance, with electrode $\mathrm{B}$ in the acid containing $0.1 \mathrm{w} / \mathrm{o} \mathrm{C}_{6}$ salt, the limiting current densities occur at the oxygen utilization of 27,18 , and $15 \%$ when oxygen flow rates of 21.4 , 34.9 , and $45.5 \mathrm{ml} \cdot \mathrm{min}^{-1} \cdot \mathrm{cm}^{-2}$ were used, respectively. These oxygen utilizations corresponds to the oxygen partial pressure of $0.58,0.70$, and 0.74 atm, respectively. In other words, the fact that the limiting current is insensitive to the oxygen partial pressure may suggest that the electrode process is under liquid-diffusion control. This current density, being insensitive to the oxygen flow rate is the one being used in the estimation of the acid film thickness.

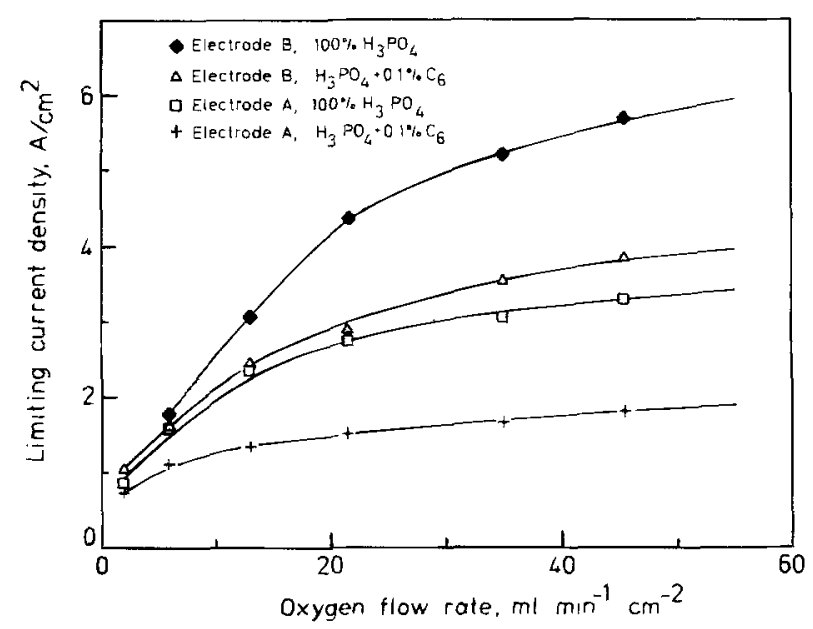

Fig. 5. Limiting current densities as a function of oxygen flow rates.

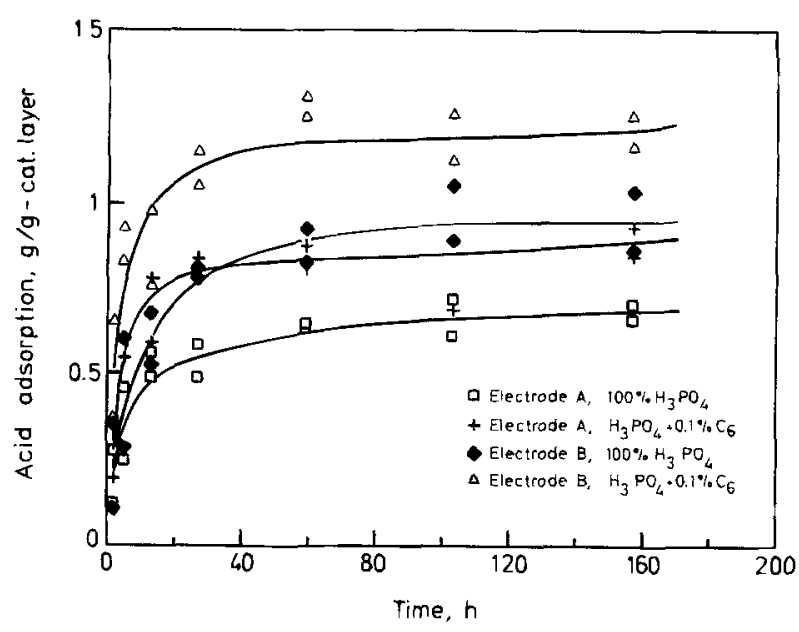

Fig. 6. Acid adsorption as a function of time.

Values of these limiting current densities were found to be $6.0 \mathrm{~A} / \mathrm{cm}^{2}$ (electrode $\mathrm{A}, \mathrm{H}_{3} \mathrm{PO}_{4}$ ), $4.0 \mathrm{~A} / \mathrm{cm}^{2}$ (electrode $\mathrm{A}$, $\mathrm{H}_{3} \mathrm{PO}_{4}+0.1 \mathrm{w} / \mathrm{o} \mathrm{C} 6$ salt), $3.5 \mathrm{~A} / \mathrm{cm}^{2}$ (electrode $\mathrm{B}, \mathrm{H}_{3} \mathrm{PO}_{4}$ ), and $2.0 \mathrm{~A} / \mathrm{cm}^{2}$ (electrode $\mathrm{B}, \mathrm{H}_{3} \mathrm{PO}_{4}+0.1 \mathrm{w} / \mathrm{o} \mathrm{C}_{6}$ salt), obtained by arbitrarily extrapolating up to the flow rate of $60 \mathrm{ml}$ oxygen per minute per $\mathrm{cm}^{2}$ in Fig. 5.

It is to be noted that the addition of $\mathrm{C}_{6}$ salt into $\mathrm{H}_{3} \mathrm{PO}_{4}$ resulted in a significant decrease in the limiting current density of oxygen reduction for both electrodes. As can be seen from $\mathrm{Eq}$. 7 and 8 , the previously demonstrated improvement in oxygen solubility $\left(c_{0}\right)$ and oxygen diffusion coefficient $(D)$ in phosphoric acid by adding the $\mathrm{C}_{6}$ salt will lead to an increase in the limiting current density (Eq. 7). However, the extra flooding of the electrode by the electrolyte containing the $\mathrm{C}_{6}$ salt will considerably reduce the reactive surface area $\left(A_{o}\right)$ and probably increase the electrolyte film thickness ( $\delta$ ) as well. The latter effect will supposedly in the present case outweigh the former one and consequently result in the sharp decrease in the limiting current density.

Acid adsorption.-Figure 6 shows the adsorption of $100 \% \mathrm{H}_{3} \mathrm{PO}_{4}$ with and without $\mathrm{C}_{6}$ salt obtained for two electrodes (A) and (B) at $150^{\circ} \mathrm{C}$. Here the acid adsorption is defined as the amount of acid absorbed by unit weight of catalyst layer of the electrode (g/g-cat. layer).

Mori et al. ${ }^{13,14}$ have found that the acid adsorption depends on time, especially in the initial $60 \mathrm{~h}$. After $100 \mathrm{~h}$, the acid adsorption tends to stabilize. For electrode A, acid adsorptions of 0.68 and $0.83 \mathrm{~g} / \mathrm{g}$-cat. layer were achieved with $100 \% \mathrm{H}_{3} \mathrm{PO}_{4}$ and $\mathrm{H}_{3} \mathrm{PO}_{4}+0.1 \mathrm{w} / \mathrm{o} \mathrm{C}_{6}$ salt, respectively, and for electrode $\mathrm{B}, 0.92$ and $1.1 \mathrm{~g} / \mathrm{g}$-cat. layer with $100 \%$ $\mathrm{H}_{3} \mathrm{PO}_{4}$ and $\mathrm{H}_{3} \mathrm{PO}_{4}+0.1$ w/o $\mathrm{C}_{6}$ salt, respectively. Gang et al. ${ }^{12}$ have shown that the addition of $\mathrm{C}_{6}$ salt in phosphoric acid will significantly improve the acid wettability on PTFE-bonded gas-diffusion electrodes. The behavior correlates well with the increased adsorption of the acid containing $\mathrm{C}_{6}$ salt for both electrodes.

Pore volume distribution and pore-wail surface area.As results of the mercury-intrusion porosimetry, Fig. 7 and 8 show the cumulative pore volume and the cumulative pore-wall surface area of the catalyst layers of electrodes $A$ and $B$. For the pores of radii up to $2.04 \mu \mathrm{m}$, the total pore volume was found to be $0.80 \mathrm{~cm}^{3} / \mathrm{g}$-cat. layer for electrode $A$, and $1.02 \mathrm{~cm}^{3} / \mathrm{g}$-cat. layer for electrode B. Assuming cylindrical pores, the total specific surface area was calculated from the pore volume by using the average pore radius $(A=2 d V / r)$, and found to be $8.0 \mathrm{~m}^{2} / \mathrm{cm}^{3}$-cat. layer for electrode $A$ and $10.4 \mathrm{~m}^{2} / \mathrm{cm}^{3}$-cat. layer for electrode $B$. Here the densities of the catalyst layers were found to be 0.41 and $0.35 \mathrm{~g} / \mathrm{cm}^{3}$ for electrode $\mathrm{A}$ and $\mathrm{B}$, respectively.

In their porosimetric analysis, Watanabe et al. ${ }^{15}$ made a distinction between micro- and macropores in the catalyst layer. Micropores are assumed to originate from the plat- 


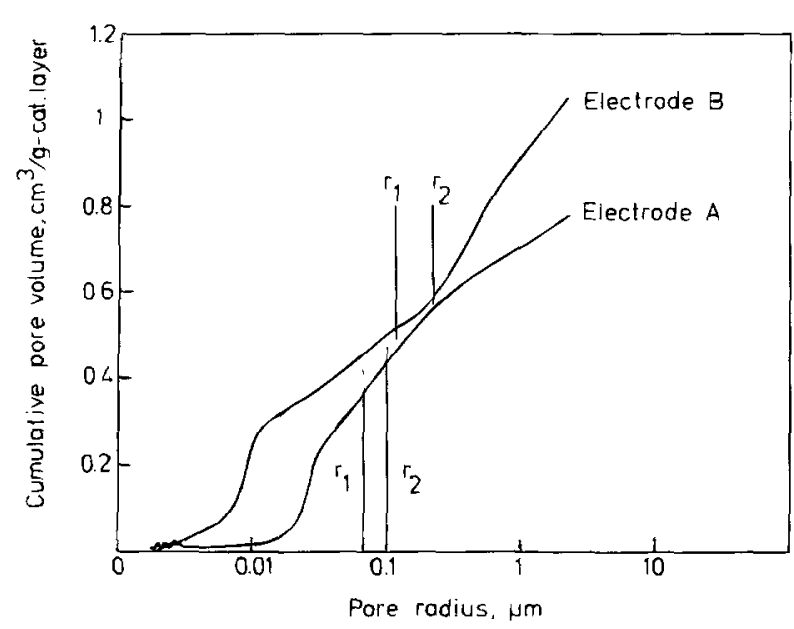

Fig. 7. Cumulated pore volume in the electrode catalyst layer as a function of pore radius for electrodes $\mathrm{A}$ and $\mathrm{B}: r_{1}$, the critical radius with $100 \% \mathrm{H}_{3} \mathrm{PO}_{4}$ and $r_{2}$, the critical radius with $\mathrm{H}_{3} \mathrm{PO}_{4}+0.1 \mathrm{w} / \mathrm{o} \mathrm{C}_{6}$ salt.

inum catalyst, while macropores are formed between the catalyst and PTFE particles. The pore radius chosen for such a differentiation was $0.1 \mu \mathrm{m} .{ }^{14,15}$ Passalacqua et al. ${ }^{16}$ made a similar discrimination with a value of $0.4 \mu \mathrm{m}$. In our case with a pore radius of $0.1 \mu \mathrm{m}$ for such a differentiation, the micropore volume was about 0.45 and $0.48 \mathrm{~cm}^{3} / \mathrm{g}-$ cat. layer for electrodes $\mathrm{A}$ and $\mathrm{B}$, respectively.

Acid-filled porosity and filmed surface area.-From the acid adsorption determined gravimetrically (Fig. 6), the pore volume occupied by acid can be evaluated, taking the density of phosphoric acid to be $1.83 \mathrm{~g} / \mathrm{cm}^{3}$. For electrode A, the acid-occupied pore volume was found to be 0.37 (or $0.45) \mathrm{cm}^{3} /$ g-cat. layer for $100 \% \mathrm{H}_{3} \mathrm{PO}_{4}$ (or $\mathrm{H}_{3} \mathrm{PO}_{4}+0.1 \mathrm{w} / \mathrm{o}$ $\mathrm{C}_{6}$ salt), and for electrode $\mathrm{B}, 0.50$ (or 0.60$) \mathrm{cm}^{3} / \mathrm{g}$-cat. layer for $100 \% \mathrm{H}_{3} \mathrm{PO}_{4}$ (or $\mathrm{H}_{3} \mathrm{PO}_{4}+0.1$ w/o $\mathrm{C}_{6}$ salt).

From distribution curves of the cumulative pore volume (Fig. 7), it is found that about $46 \%$ (or $56 \%$ ) of total pore volume of electrode $\mathrm{A}$ was occupied by phosphoric acid (or acid with $0.1 \mathrm{w} / 0 \mathrm{C}_{6}$ salt) and $49 \%$ (or $59 \%$ ) for electrode $\mathrm{B}$.

It should be remarked that the mercury porosimetry is performed on the basis of Eq. 3 and constant contact angle $\theta$. In the case of a PTFE-bonded electrode, however, the contact angle, $\theta$, is not constant, and apparently different for mercury and phosphoric acid. In spite of this fact, it might be true to assume that phosphoric acid predominantly occupies the volume of the smaller pores determined by mercury-intrusion porosimetry. In this way, it is found

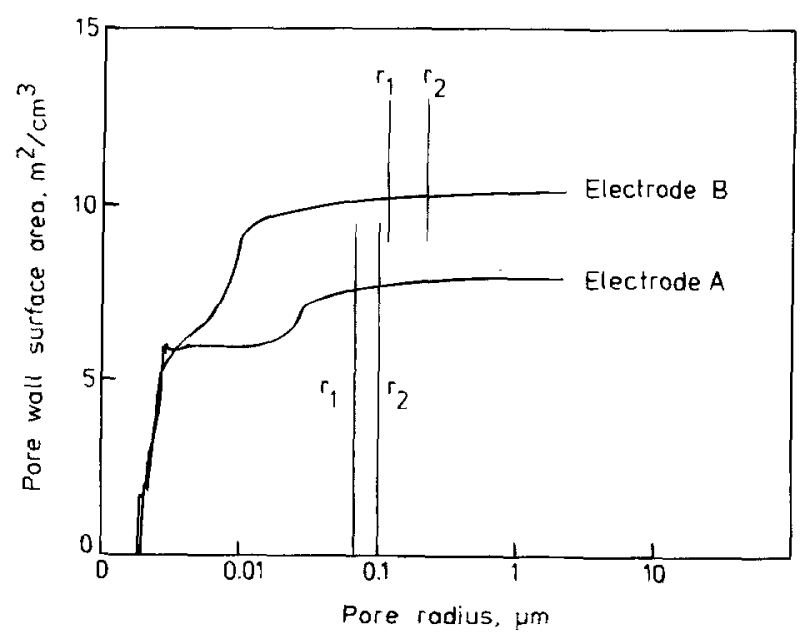

Fig. 8. Pore-wall surface area as function of pore radius for electrodes $A$ and $B: r_{1}$, the critical radius with $100 \% \mathrm{H}_{3} \mathrm{PO}_{4}$ and $r_{2}$, the critical radius with $\mathrm{H}_{3} \mathrm{PO}_{4}+0.1 \mathrm{w} / 0 \mathrm{C}_{6}$ salt.
Table I. Summary of the calculation of the acid-film thickness.

\begin{tabular}{|c|c|c|c|c|}
\hline & \multicolumn{2}{|c|}{ Electrode A } & \multicolumn{2}{|c|}{ Electrode B } \\
\hline & $\overline{\mathrm{H}_{3} \mathrm{PO}_{4}}$ & $+0.1 \mathrm{w} / \mathrm{o} \mathrm{C}_{6}$ & $\mathrm{H}_{3} \mathrm{PO}_{4}$ & $+0.1 \mathrm{w} / \mathrm{OC}_{6}$ \\
\hline$D_{C} / 10^{12}(\mathrm{~mol} \cdot \mathrm{cm} \cdot \mathrm{s})$ & 8.9 & 11.0 & 8.9 & 11.0 \\
\hline$z / 10^{3}(\mathrm{~cm})$ & 5.0 & 5.0 & 5.0 & 5.0 \\
\hline$i_{\mathrm{L}}\left(\mathrm{A} / \mathrm{cm}^{2}\right)$ & 6.0 & 4.0 & 3.5 & 2.0 \\
\hline $\begin{array}{l}\text { Pore volume }\left(\mathrm{cm}^{3} /\right. \\
\text { g-cat. layer })\end{array}$ & 0.80 & 0.80 & 1.02 & 1.02 \\
\hline $\begin{array}{l}\text { Acid volume }\left(\mathrm{cm}^{3} /\right. \\
\text { g-cat. laver }\end{array}$ & 0.37 & 0.45 & 0.50 & 0.60 \\
\hline Critical radius $/ 10^{6}(\mathrm{~cm})$ & 6.7 & 10.1 & 11.5 & 22.0 \\
\hline $\begin{array}{l}\text { Filmed area } / 10^{3} \\
\left(\mathrm{~cm}^{2} / \mathrm{cm}^{3}\right)\end{array}$ & 3.61 & 2.34 & 1.86 & 1.04 \\
\hline Film thickness $(\mu \mathrm{m})$ & 0.09 & 0.12 & 0.10 & 0.13 \\
\hline $\begin{array}{l}r_{\alpha} / 10^{4}(\mathrm{~cm}) \\
(1 \%)(\%)\end{array}$ & 4.48 & 7.20 & 8.66 & 16.1 \\
\hline $\begin{array}{l}(\%) \\
N / 10^{-7}\end{array}\left(\mathrm{~cm}^{3}\right)$ & $\begin{array}{l}21 \\
25.7\end{array}$ & $\begin{array}{l}24 \\
10.4\end{array}$ & 23 & 25 \\
\hline
\end{tabular}

that, for electrode $\mathrm{A}$, pores smaller than the critical radii 0.067 (or 0.101 ) $\mu \mathrm{m}$ are filled with phosphoric acid (or acid with $0.1 \mathrm{w} / 0 \mathrm{C}_{6}$ salt), and for electrode $\mathrm{B}$, pores smaller than 0.115 (or 0.220$) \mu \mathrm{m}$ in radii are filled with phosphoric acid (or acid with $0.1 \mathrm{w} / \mathrm{o}_{6}$ salt).

As discussed in the section concerning limiting current density, both thin-film models and filmed agglomerate models assume that the electrochemically active area can be estimated from the pore-wall surface area of pores larger than the critical radius. This is done in the present work by assuming that the pore-wall surface area determined by mercury porosimetry can be used for phosphoric acid. From Fig. 8, the specific pore-wall surface area of electrode $\mathrm{A}$, corresponding to pores above the critical radii of 0.067 (or 0.101 ) $\mu \mathrm{m}$ was found to be 3610 (or 2340 ) $\mathrm{cm}^{2}$ / $\mathrm{cm}^{3}$, and that for electrode B to be 1860 (or 1040) $\mathrm{cm}^{2} / \mathrm{cm}^{3}$. These values will be used in the estimation of the acid-film thickness below.

Thickness of acid film.-Table I summarizes the data used and obtained in the calculation of the acid-film thickness. Here the product of the oxygen solubility and the oxygen diffusion coefficient in $100 \% \mathrm{H}_{3} \mathrm{PO}_{4}$ at $150^{\circ} \mathrm{C}$ was taken from Ref. 12, and that for phosphoric acid with $0.1 \mathrm{w} / \mathrm{o} \mathrm{C}_{6}$ salt was estimated by considering the value for $100 \% \mathrm{H}_{3} \mathrm{PO}_{4}$ and the value $\left(11.71 \times 10^{-12} \mathrm{~mol} \cdot \mathrm{cm}^{-2}\right.$. $\mathrm{s}^{-1}$ ) for phosphoric acid with $0.5 \mathrm{w} / \mathrm{o} \mathrm{C}_{6}$ salt at the same temperature. ${ }^{12}$

The cumulative pore volume was obtained from the mercury porosimetry. The pore volume occupied by acid was obtained from the acid-adsorption measurement, based on which the critical pore radius was determined from the distribution curve of the pore volume. From the critical pore radius thus obtained, the reactive pore-wall surface area covered with the acid film was evaluated from the curve of the cumulative surface area as function of the pore radius. By using Eq. 7 and 8, the film thickness was then evaluated.

The resulting values of the acid-film thickness for both electrodes with phosphoric acid, either with or without $\mathrm{C}_{6}$ salt, are of the $0.1 \mu \mathrm{m}$ order of magnitude. The presence of $\mathrm{C}_{6}$ salt as an additive in $\mathrm{H}_{3} \mathrm{PO}_{4}$ seems to enlarge the acidfilm thickness.

The last three rows of data in Table I are the agglomerate parameters evaluated for the filmed agglomerate model, using Eq. 9, 10, and 12. It is seen from the resulting agglomerate properties that, when the acid occupation increases as a result of adding $\mathrm{C}_{6}$ salt into $\mathrm{H}_{3} \mathrm{PO}_{4}$, the number of agglomerates decreases while the agglomerate radius increases. These will lead to a greater liquid-phase diffusion polarization, as predicted by the filmed agglomerate model. $^{7}$

\section{Conclusions}

The limiting current density due to the diffusion rate control has been determined for oxygen reduction on the PTFE-bonded porous electrodes. Two types of diffusion were encountered, i.e., gas-phase diffusion at low oxy- 
gen flow rates and liquid-phase diffusion at high oxygen flow rates.

It is important to mention that for the electrode process under control of liquid-phase diffusion, both the thin-film model and the filmed agglomerate model reach the same expression for the limiting current density. As a consequence, this limiting current density can be used to determine the acid-film thickness, which is a critical parameter in the modeling of porous electrodes.

By combining the acid-adsorption measurements and the porosity analysis of the catalyst layer of the electrode, it proved possible to determine the acid occupation, the available specific pore-wall surface area, and some other agglomerate properties such as agglomerate radius, agglomerate porosity, and agglomerate number on the basis of the filmed agglomerate model. Finally the acid film thickness was evaluated with the help of the experimentally measured limiting current density for two types of electrodes in phosphoric acid electrolytes with and without fluorinated additives.

\section{Acknowledgments}

The authors are grateful to Haldor Topsøe A/S for financial support and for performing the porosity measurements. Danish International Development Agency (DANIDA) is thanked for a scholarship provided to one of the authors (LQF)

Manuscript submitted March 7, 1994; revised manuscript received June 6, 1994.

\section{REFERENCES}

1. S. Srinivasan and H. D. Hurwitz, Electrochim. Acta, 12, 495 (1967).

2. G. Wilemski, This Journal, 130, 117 (1983).

3. J. Giner and C. Hunter, ibid., 116, 1124 (1969).

4. W. Vogel, J. Lundquist, and A. Bradfort, Electrochim. Acta, 17, 1735 (1972)

5. C. Y. Yuh and J. R. Selman, This Journal, 131, 2062 (1984).

6. C. Y. Yuh and J. R. Selman, ibid., 139, 1373 (1992)

7. H. R. Kunz, L. J. Bregoli, and S. T. Szymanski, ibid., 131, 2815 (1984)

8. J. Mitteldorf and G. Wilemski, ibid., 131, 1784 (1984).

9. T. E. Springer and I. D. Raistrick, ibid., 136, 1594 (1989).

10. J. R. Selman, W. L. Lo, T. E. Tang, and T. D. Claar, Abstract 128 , p. 349 , The Electrochemical Society Extended Abstracts, Vol. 80-2, Hollywood, FL, Oct. 5-10, 1980.

11. X. Gang, H. A. Hjuler, C. Olsen, R. W. Berg, and N. J. Bjerrum, Danish Pat., 167946.

12. X. Gang, H. A. Hjuler, C. Olsen, R. W. Berg, and N. J. Bjerrum, This Journal, 140, 896 (1993).

13. T. Mori, J. Imahashi, T. Kamo, K. Tamura, and Y. Hishinuma, ibid., 133, 896 (1986).

14. T. Mori, A. Honji, T. Kahara, and Y. Hishinuma, ibid., 135, 1104 (1988)

15. M. Watanabe, M. Tomikawa, and S. Motoo, J. Electroanal. Chem., 195, 81 (1985)

16. E. Passalacqua, P. Staiti, L. Pino, M. Vivaldi, N. Giordano, E. J. Taylor, and G. Wilemski, Int. J. Hydrogen Energy, 17, 771 (1992).

\title{
Fischer-Tropsch Electrochemical $\mathrm{CO}_{2}$ Reduction to Fuels and Chemicals
}

\author{
Michael Schwartz, Mark E. Vercauteren, and Anthony F. Sammells*
}

Eltron Research, Incorporated, Boulder, Colorado 80301

\section{ABSTRACT}

This investigation was directed toward the rational selection of cathode electrocatalysts compatible with promoting carbon dioxide reduction at practical rates to commercially significant fuels and chemicals. Work performed identified electrocatalyst sites, incorporated into gas-diffusion electrodes, demonstrating high activity toward promoting both $\mathrm{CO}_{2}$ reduction to adsorbed $\mathrm{CO}$ and subsequent electron transfer leading to final reaction products. The feature of electrocatalysis identified was in its apparent ability to maintain a high coverage of adsorbed CO intermediate species at reaction sites available for further reduction to products. Carbon dioxide reduction proceeded at significantly lower overpotentials and higher rates and faradaic efficiencies than previously found to this time at unit-activity copper.

Our objective was to characterize and evaluate novel electrocatalyst alloys and bimetallics as sites for promoting what we had previously referred to as electrochemical Fischer-Tropsch $(E F T) \mathrm{CO}_{2}$ reduction. ${ }^{1}$ Electrocatalyst alloys and bimetallic mixtures, which initially emphasized, respectively, $\mathrm{Cu}: \mathrm{Pb}, \mathrm{Cu}: \mathrm{Ag}, \mathrm{Ag}: \mathrm{Pb}, \mathrm{Cu}: \mathrm{Cd}, \mathrm{Cu}: \mathrm{Zn}, \mathrm{Cu}: \mathrm{Mn}$, and $\mathrm{Ag}: \mathrm{Mn}$, were predicted by us to exert a favorable influence on either electrochemical rate or cathode overpotential (ideally both) required for promoting $E F T \mathrm{CO}_{2}$ reduction to fuels and chemicals, compared to that previously found with unit-activity copper cathodes.

Cathode electrocatalyst selection was based on insights developed at Eltron from recent experimental work performed both by ourselves ${ }^{1-10}$ and others ${ }^{11-13}$ on electrochemical $\mathrm{CO}_{2}$ reduction in aqueous electrolyte and in the gas phase. Our investigations had suggested that the pathway through which electrochemical $\mathrm{CO}_{2}$ reduction proceeded was via formation of intermediate $\mathrm{CO}$, followed ${ }^{*}$ by potential assisted $\mathrm{C}-\mathrm{O}$ splitting to give an adsorbed carbon type intermediate. This intermediate could then become hydro-

* Electrochemical Society Active Member. genated to give carbene, leading to either hydrocarbon or alcohol reaction products.

Analysis performed at Eltron, ${ }^{1}$ using experimental data obtained by others, ${ }^{17}$ had shown that, with the exception of copper, all metal electrocatalytic sites possessing activity toward promoting $\mathrm{CO}_{2}$ reduction had activity favoring either reduction to $\mathrm{CO}$ or reduction of $\mathrm{CO}$ to hydrocarbons, but not both. Copper appeared to be the only exception to this observation in that it possessed high activity for promoting both electrochemical $\mathrm{CO}_{2}$ reduction to $\mathrm{CO}$ and subsequent $\mathrm{CO}$ reduction to hydrocarbons.

The above insights were found by our group ${ }^{1}$ sing multivariate analysis of $\mathrm{CO}_{2}$ reduction product distribution to gain insight into the relative propensities of metal electrocatalysis toward promoting $\mathrm{CO}_{2}$ reduction to $\mathrm{CO}$ and subsequently to gaseous hydrocarbons and potentially other useful $\mathrm{CO}_{2}$ reduction products. Results from this analysis suggested that one approach for data interpretation was to determine relative electrocatalyst activities toward $(i)$ reducing $\mathrm{CO}_{2}$ to $\mathrm{CO}$ and (ii) subsequently reducing $\mathrm{CO}$ to hydrocarbons. In our analysis we assumed that hydrocar- 